\title{
Sense of (Un)Belonging: Acculturation Experiences among Second-Generation Migrants from Bosnia and Herzegovina
}

DOI: https://doi.org/10.11567/met.35.3.3 UDK: $314.15-054.7]: 316.732(=163.4)$

Izvorni znanstveni rad Primljeno: 20.02.2020. Prihvaćeno: 02.05.2020.

\section{Bojana Vukojević}

Department of Sociology, Faculty of Political Sciences, University of Banja Luka bojana.vukojevic@fpn.unibl.org

\begin{abstract}
SUMMARY
Contemporary migration research shows that the number of foreign-country-born migrants is increasing, which highlights the significance of research on second-generation migrants as a particular group that can expose the specifics of development courses of migrants' life and cultural identity. The term "second generation" refers to people born in a host country, to at least one immigrant parent or people who emigrated from the country of origin at the age of 6 or less. On the other hand, the 1.5 generation (persons born in a foreign country who emigrated during the early adolescence - between 6 and 12 years old) does not exhibit a unique cultural identity but feels divided between belonging to the country of origin and the host country. According to migration studies, the second generation shows a better level of acculturation, owing to the easier learning of the language(s) and adaptation to educational and work habits. This paper explores different theoretical models (unidimensional, bidimensional, and interactive), in order to establish a framework for acculturation experiences of second-generation migrants from Bosnia and Herzegovina. Using a discourse analysis of the life stories of six second-generation emigrants from Bosnia and Herzegovina, an interpretation framework will be created consisting of three topics: self-determination and construction of identity; primary socialisation impact on the (in)homogeneity of cultural identity; connection of the second generation with the country of origin and the host country. One of the most important conclusions is that the second generation has no clearly defined identity (which is symptomatic for the 1.5 generation) and that their daily lives are marked by an intense feeling of not belonging - neither there nor here.
\end{abstract}

KEY WORDS: second generation, migration, acculturation, identity, belonging

Contemporary research on immigrant societies indicates a clear social distinction between immigrants and their offspring born abroad on the one hand and indigenous people on the other (Alba, 2005; Portes and Zhou, 1993). ${ }^{1}$

1 This paper was supported by the Ministry of Civil Affairs of Bosnia and Herzegovina under the Grant Programi za pripremu projekata i potencijalnih kandidata za sredstva iz fonda EU FP7 za 2015. godinu (Preparation Programmes for Projects and Potential Applicants for the 2015 EU FP7 Funds) [Grant contract number: 10-33-15-1040/15-39]. 
The transcultural practices of Bosnian expatriates draw special attention in studies of migrants' experiences and life strategies in relation to the place of origin, as well as their liminality (Savić, Pepić and Trninić, 2018; Kostić, 2013; Valenta and Strabac, 2013). Some studies have examined the possibility of establishing transnational economic practices of refugees from $\mathrm{BiH}$, and, having considered the historical context, cultural and political factors, they concluded that it was premature to talk about transnational communities, but rather about emerging transnationalism (Al-Ali, Black and Koser, 2001). These changes in the making are related to strong symbolic relations with the country of origin, which are not strong enough to make many economic commitments besides financial aid or remittances. Emigrants from $\mathrm{BiH}$ maintain their connections with the country of origin mostly through personal (family) networks and contacts, without economic commitments in their local municipalities, despite some expectations about rebuilding local communities and empowering national development (Babić, 2013). This lack of ties that bind the first generation to their homeland is the beginning of a redefinition of their identity and a very important factor in the socialisation of the second generation of immigrants. The first generation of immigrants refers to those who were born in a foreign country and emigrated from it as adults (after the age of 12). Generation 1.5 refers to the immigrants who were born in and emigrated from a foreign country during adolescence (between the ages of 6 and 12). The second generation encompasses the immigrants who were born in the country of destination to at least one immigrant parent or who immigrated to the country of destination before they turned 6 (Portes, 1997). The boundary between the immigrants and the locals is most often exacerbated by the dominant cultures, which additionally implies a need to study the second generation of migrants as a special group that can indicate the specificities of migrant life and the directions of cultural identity development.

\section{METHODOLOGY}

The data used in this paper was derived from broader research conducted during 2016 at the Faculty of Political Sciences, the University of Banja Luka as a part of the project entitled "Life Projects of Young (Re)Emigrants from Bosnia and Herzegovina". This research was based on a convergent parallel mix-method design (Creswell, 2013), which implies that qualitative and quantitative data were collected using the following techniques in parallel: an online survey (350 respondents) and an (auto)biographical narrative interview (10 respondents per migrant subgroup). According to the estima- 
tions made by the World Bank, $44.5 \%$ of the total population of BiH lives abroad, and these are only the data related to the first generation of emigrants (Bosnia and Herzegovina Ministry of Security, 2019: 70). Apart from this and other estimations, considering that Bosnia and Herzegovina has no official register of emigrants, as well as no register of their descendants (i.e. there is no sampling frame), snowball sampling was used - a well-known non-random technique that involves using interviewees to identify additional participants who may be included in a further interviewing process (Teddlie and Tashakkori, 2009: 156).

This paper is based on the results of a discourse analysis of life stories of six second-generation emigrants. The structure of the respondents shows different ethnic backgrounds, destination countries, lack of language barriers, and similar age at the time of emigration (Table 1). All of these characteristics will show no effect on identity divisions among the second generation.

Table 1. Characteristics of interviewees

\begin{tabular}{|c|c|c|c|c|c|c|c|}
\hline & $\begin{array}{l}\text { Age at the } \\
\text { time of } \\
\text { emigration }\end{array}$ & $\begin{array}{c}\text { Current } \\
\text { age }\end{array}$ & Sex & $\begin{array}{l}\text { Destination } \\
\text { country }\end{array}$ & $\begin{array}{c}\text { Ethnic } \\
\text { background }\end{array}$ & Language(s) & $\begin{array}{c}\text { Migration } \\
\text { status }\end{array}$ \\
\hline $\begin{array}{l}\text { Interviewee } \\
\text { EX1 }\end{array}$ & $\mathrm{n} / \mathrm{a}$ & $\mathrm{n} / \mathrm{a}$ & Male & Finland & Bosniak & $\begin{array}{l}\text { Bosnian, } \\
\text { Finnish, } \\
\text { English }\end{array}$ & Emigrant \\
\hline $\begin{array}{l}\text { Interviewee } \\
\text { EX2 }\end{array}$ & 4 & 29 & Female & Canada & Serbian & $\begin{array}{l}\text { Serbian, } \\
\text { English, } \\
\text { French }\end{array}$ & Emigrant \\
\hline $\begin{array}{l}\text { Interviewee } \\
\text { EX3 }\end{array}$ & 6 & 33 & Male & $\begin{array}{c}\text { Italy/ } \\
\text { Norway/ } \\
\text { Switzerland }\end{array}$ & Serbian & $\begin{array}{l}\text { Serbian, } \\
\text { Italian, } \\
\text { English, } \\
\text { Norwegian, } \\
\text { German }\end{array}$ & Emigrant \\
\hline $\begin{array}{l}\text { Interviewee } \\
\text { EX4 }\end{array}$ & $\begin{array}{c}\text { Born in } \\
\text { emigration }\end{array}$ & 26 & Male & $\begin{array}{l}\text { Germany/ } \\
\text { Sweden }\end{array}$ & Bosniak & $\begin{array}{l}\text { Bosnian, } \\
\text { German, } \\
\text { English }\end{array}$ & $\begin{array}{c}\text { Returning } \\
\text { migrant }\end{array}$ \\
\hline $\begin{array}{l}\text { Interviewee } \\
\text { EX5 }\end{array}$ & 4 & 29 & Female & Canada & Serbian & $\begin{array}{l}\text { Serbian, } \\
\text { English, } \\
\text { French }\end{array}$ & Emigrant \\
\hline $\begin{array}{l}\text { Interviewee } \\
\text { EX6 }\end{array}$ & 4 & 30 & Male & Canada & Serbian & $\begin{array}{c}\text { Serbian, } \\
\text { Slovenian, } \\
\text { English, } \\
\text { French }\end{array}$ & Emigrant \\
\hline
\end{tabular}

Starting from a social constructivist methodological framework, where knowledge and reality are created through social relationships and interactions, collecting life stories or recollections of the children of $\mathrm{BiH}$ emigrants 
provided us with a great amount of data. During the gathering of this oral history, recollections are often imperfect and memories are distorted (Neuman, 2007: 314), but these kinds of personal narratives proved to be valuable as an alternative way of understanding how the everyday life of second-generation emigrants consists of continuous self-reflection, softens traditional and shapes new forms of identities. Discourse analysis enables us to study conflicts, suppressions, and institutionally formed subjectivity shaped by the power of discourses in a given social and cultural context (Clough et al., 2004). The framework of interpretation consists of three themes: self-determination and identity-building; the impact of primary socialisation on the (in)homogeneity of cultural identity; the connection of the second generation with the country of origin and the host country. A descriptive phenomenological method was used to analyse the data (Morrow, Rodriguez and King, 2015).

\section{PROBLEM FORMULATION}

The subject matter of this research is the second generation of expatriates from Bosnia and Herzegovina. The theoretical framework of the paper includes the theories of acculturation and the development of transcultural models of immigrants in immigrant societies. In this sense, the inevitable actors of the acculturation process are any immigrant group or individual who goes through the expatriation experience. Cultural contact and permanence as the basic predispositions of acculturation are established in the case of second-generation immigrants. The paper aims to answer the following questions: in what direction does their sense of belonging develop, do they follow the general trends of the members of this population, according to which model does their cultural identity develop and what is their connection with the country of origin?

\section{THEORETICAL BACKGROUND}

\section{Acculturation}

Acculturation is a concept explaining the dynamics and processes that arise when groups and individuals of different cultural backgrounds come into cultural contact, that is when individuals and groups move from their native cultural backgrounds into a new socio-cultural environment. This complex process has been researched through different aspects of observing the directions of the development of immigrant cultures. Accordingly, differ- 
ent theoretical concepts and models of acculturation developed. Unidimensional models, which often entail identification of acculturation and assimilation (thereby supporting the melting pot discourse), provided a basis for the development of bidimensional and interactive perspectives that implied different outcomes of acculturation.

The unidimensional model of acculturation, which is synonymous with assimilation, was presented by Milton Gordon in his study of American immigrants. Gordon's theoretical model is concerned with researching the effects of acculturation at the macro level, through the types of assimilation that take place at the individual and group levels. Gordon proposes a model that includes several types of assimilation: cultural assimilation, structural assimilation, marital assimilation, identification assimilation, attitude receptive assimilation, and behavioural assimilation. Cultural assimilation is the first process that involves changing the cultural patterns of an immigrant group under the influence of the cultural patterns of the dominant group in the host country (Gordon, 1964: 77). According to Gordon, structural assimilation and marital assimilation (or amalgamation, when it comes to the melting pot context) are inseparable and imply each other over a period of time. According to this concept, once cultural assimilation takes place, all other processes will occur simultaneously. Marital assimilation will lead to the drowning of the ethnic identity of the minority and the development of a sense of belonging based on a dominant culture (identity assimilation). As a by-product of this, prejudice (attitude receptional assimilation) and discrimination (behavioural receptional assimilation) will disappear. If this assimilation takes place completely, an inter-group sentiment will be created, preventing the value conflict between the descendants of the minority and the members of the host culture (Gordon, 1964: 80-81). What is interesting about this author's theory, and especially in the context of the present research, is an explanation of American cultural pluralism. The process of acculturation does not end with merging into one group, but with further stratification into a network of subgroups (e.g. religious, intellectual, etc.), in which life is organised in smaller communities with occasional contacts with outsiders and minimal civic (political) engagement. The disadvantages of this theory are reflected in the fact that they imply the uniformity of all immigration, that is, the equality and fairness of interests of immigrants, as well as the goals of immigration (set by the host country).

Portes and Zhou offer a different theory of acculturation, which incorporates socioeconomic factors and assumes segmented assimilation. Accord- 
ing to these authors, the acculturation process takes several forms. The first is acculturation and parallel integration into the white middle class, the second is acculturation directed at poverty and assimilation into the subclass, and the third implies rapid economic progress while preserving tradition, values, and ethnic solidarity within immigrant networks (Portes and Zhou, 1993: 82). The outcome depends on the complex environment that immigrants come into, which consists of the immigrant policies of the host country, the prejudices and stereotypes of the host society, as well as the characteristics and structures of their own ethnic community.

As a consequence of the criticism of unidimensional acculturation theories, bidimensional theories emerged, most prominently represented by John Berry, who developed a model comprising four acculturation strategies. Berry (1992) assumes that, in culturally plural societies, two dimensions are crucial to the acculturation of immigrants, that is, immigrants are faced with two issues: 1) whether it is worthwhile to retain certain values and diversity of one's ethnic identity in society; 2) whether there is a need for cultural contact, that is, whether they want to interact with the wider society. Through dichotomous answers (yes or no), Berry developed a quadruple model comprising the following strategies that emerged from the answers to the previous questions: assimilation, integration, separation, and marginalisation. When the answer to the first question is negative and the second is affirmative, assimilation occurs, implying a renunciation of the cultural identity of the past and melting into the dominant culture (the melting pot discourse). Where there is a desire to preserve the cultural integrity of one's ethnic group but also to integrate into the life of the dominant group, integration takes place. When there are no significant links with the dominant group, two outcomes are possible, depending on which group has the power to direct such an acculturation development. If the dominant group imposes a pattern in which immigrants should be kept aside, segregation occurs. If the immigrant group seeks to maintain tradition and refrain from participating in the life of the dominant group, it is a case of separation. The last of the possible outcomes of acculturation is marginalisation, which is the result of non-alignment with the dominant group combined with a sense of alienation, that is, loss of identity of one's group. Thus, marginalisation can occur either by exclusion or withdrawal of an individual or a group (Berry, 1992).

More recent research acknowledges the roles of all parties in the process of acculturation, that is, the interactions that are necessarily established 
between immigrants and the dominant culture. Bourhis et al. (1997) have created an interactive acculturation model (IAM), which seeks to show that there are more variants of acculturation outcomes than Berry's square model shows. The IAM considers the acculturation orientations of immigrant groups, the acculturation orientations of the dominant culture towards immigrant groups, and the relative outcomes at the individual and group levels, which are a combination of both acculturation orientations. In this way, the interactive model envisages integration, assimilation, segregation, exclusion, and individualism as acculturation orientations of the host culture. On the other hand, the acculturation orientations that emerge from immigrant strategies toward the domestic culture include consensual (intergroup harmony), problematic (partial agreement), and conflict (intergroup conflict) outcomes. The authors of this model emphasise that none of the outcomes is exclusive, that is, strategies that assume open immigration policies or civic ideology do not guarantee that no segregation will be initiated by a part of the host community, nor that certain immigrant groups will not have separatist or exclusivist pretensions. What this model does not say is what subgroups or classes adopt such strategies, or deviate from them, since the model is quite abstract and does not include the social or economic dimensions of the groups developing particular acculturation orientations (Bourhis et al., 1997: 384).

A review of these theories discusses the complexity of the conditions under which migration takes place, as well as the factors that determine the outcomes of acculturation. Therefore, interactive acculturation theories are a necessity in the study of second-generation migrants, because they constitute a distinct variable whose strategies are shaped by different traditions, as well as simultaneous exposure to different cultures, including mass culture. The issue of identity is no longer raised in opposing categories, but transculturalism is also taken into account.

"We define 'transnationalism' as the processes by which immigrants forge and sustain multi-stranded social relations that link together their societies of origin and settlement" (Basch, Glick Schiller and Szanton Blanc, 1994: 8). Transculturalisam or transnationalism is an important indicator of future migration flows. According to some contemporary studies of migration (Vertovec, 2001; De Haas, 2005), transnationalism indicates new forms of collective identity and new forms of circular and return migration. Good integration into host society does not have to imply a lack of relations with the country of origin, and vice versa - good contacts and attachment to 
the origin country does not have to be a sign of weak integration into the receiving society. "After all, successful and 'integrated' migrants generally also dispose of increased cognitive and financial capacity for setting up enterprises and participating in public debate in their countries of origin" (De Haas, 2005: 1276).

\section{Identity}

Processes of acculturation and the theories that have dealt with them are inseparable from the dominant identity issue of today. However, years before the term was established, some theories were addressing the outcomes of acculturation processes and their consequences. The theory of marginal man is well-known in the field of psychological theories that treat divisions in clear self-identification. It is a sociological concept first coined by Robert Ezra Park in the 1920s. The theory explains how an individual, torn between two cultures, can undergo a struggle to establish his or her identity. The term "marginal person" means an individual exposed to the influence of two different ethnic or racial groups. "One of the consequences of migration is to create a situation in which the individual [...] finds himself driven to live in two diverse cultural groups. The effect is to produce an unstable character - a personality type with characteristic forms of behaviour. This is the Marginal Man" (Park, 1928: 881). This concept was primarily developed in relation to African-American social groups and the emergence of interracial marriage in the United States. It is this concept that is referred to when discussing marginalisation as the outcome of acculturation in the theories presented earlier in the text.

\section{Second generation}

For further observation of the cultural identity of expatriates from Bosnia and Herzegovina, it is important to note one terminological distinction. As part of the research on expatriates from Bosnia and Herzegovina, there was a need to discuss the "1.5" generation. This term has been used in American sociology since the 1960s: sociologist Rubén Rumbaut used it to describe Asian-American adolescents and young adults. Today, this unique term is used for US immigrants who arrived in the US as children or adolescents. Unlike their parents who represent the first generation of immigrants or their relatives born in the US, the identity of generation 1.5 is divided. Their age at the time of immigration, as well as whether their parents are of the same or different origin, will largely determine their position in the cultural 
processes - will they play a constructive role in the interpretation of culture and bridge differences, will they develop a pan-ethnic identity or, in the third scenario, will they be in-between - neither there nor here (Portes and Rumbaut, 2001)?

There are significant differences between the first and second generation of immigrants in terms of the physical and psychological stages of development, the process of socialisation within the family, school, and society, as well as the orientation towards the homeland (Zhou, 1997). Research conducted by Alejandro Portes and Ruben Rumbaut (2001) shows that those who immigrated at the age of 6 or younger are more similar to their peers originating in the receiving country when it comes to language skills, academic behaviour, and cultural assimilation. Research by these authors regarding the distinction within immigrant groups in the United States has indicated that the differences are related to age and stage of life at the time of immigration, and are considered theoretically important to analyse acculturation modalities among immigrants and their parents. The authors cited these variants under the names "dissonant", "consonant", and "selective" acculturation (Portes and Rumbaut, 2001: 53-54).

Dissonant acculturation marks the process in which children outgrow their parents when adopting the English language and the American way of life, in parallel with the loss of their native culture. In this situation, a role reversal occurs since parents cannot function successfully in society without the help of their children. Consonant acculturation is a reversed situation, in which the learning process and the gradual abandonment of the mother tongue and culture take place at approximately the same pace in both generations. Selective acculturation occurs when the learning process of both generations is directed by a larger ethnic community that is adequately institutionally constructed, which slows down the changes brought about by the contact with the host culture and promotes partial retention of the parents' native language and norms. This option implies a lack of intergenerational conflicts, building social capital within the native community, and achieving second-generation bilingualism (Portes and Rumbaut, 2001: 53-54). When it comes to language assimilation, overcoming language barriers is the first step that allows an individual to become part of a larger community, gain an education, get a job, etc. Interestingly, this is the initial barrier in immigrant communities, for the most uneducated, as well as the educated groups. However, assimilation through language is expected of immigrants not only for instrumental reasons but also for symbolic ones, 
since the essence of national identities and ethnic solidarity rests in the language (Portes and Rumbaut, 2001).

A second generation is a group exposed to the influences of at least two cultures. In such contacts, changes in the cultural patterns of minority groups are certain. Whether the second generation will have all the hallmarks of distinguishing itself from the dominant group as well as the first generation depends largely on the dominant culture of the receiving country. The majority group always seeks to impose a social distance between itself and minority cultures, ensuring that the characteristics and values of its culture are valued in important institutions. The distance being built, or the boundaries that are being established, can be clear or blurred. "But the construction of immigrant native boundaries is, in each society, a path-dependent process that hinges on the materials available in the social-structural, cultural, legal, and other institutional domains of the receiving society, as well as on characteristics and histories that the immigrants themselves present. Hence, boundaries do not have the same character everywhere; and though invariably they do allow for some assimilation to occur, the terms under which this happens vary from one societal context to another" (Alba, 2005: 41). Such outcomes lead us to think of transculturalism as a certain model of cultural identity. Transculturalism is a highly represented concept not only in research on migration but as a conceptualisation of culture, as an active factor in our cultural life.

\section{RESULTS}

\section{Self-determination and identity building}

When discussing self-identification, respondents hesitate to define themselves by how they perceive themselves but project their identities according to how they think others perceive them. Although their emigration ended many years ago, it is symptomatic that there is no rootedness in the country of origin, nor in the new environment, which is symbolically expressed by describing the country in which they live as a foreign country, abroad.

Most people know what it's like, it's not just living abroad. There is definitely a difference. You're not kind of home when you go there [to your country of origin], definitely. (EX1)

The otherness of an individual in a culturally pluralistic community makes his self-identification problematic. 
They do not perceive me differently, but they see me as not being other. I often hear it, so they ask me, then when I explain to them my life story, someone understands it, someone can't. They say "you are Bosnian, you have to be that", but people cannot understand that they should not push anyone to be someone or something if they do not feel like it. (EX3)

The respondent who, despite her good integration into a multicultural society, expresses ambivalence when trying to determine her own affiliation, thus reveals a deep-seated perception inherited from parents, who are the first generation of immigrants, that affiliation is determined on the principle of ius salt. In addition to family upbringing rooted in, traditionally, ethnically and culturally homogeneous communities, coexistence with different cultures has resulted in the loss of cultural authenticity and indications of hybrid identity formation.

I think a hybrid identity is being created, because for example here, my closest friends are mostly Serbs from different places. [...] I could never identify myself as a Canadian, since it means something to me. In my definition, Canadians are people from Canada who were born here, who have lived here for generations, and maybe that's why I have a different perception, while to someone else it would just mean someone living in Canada. (EX2)

Although the interviews suggested that most respondents had a good understanding of their immigrant life and position in the host country, whether they viewed it as good integration or as ghettoisation, they did acknowledge in their replies that they were troubled by a sense of belonging. There was a sense of dislike, a sense of marginality, a symptom of the so-called "marginal individual".

It starts with people asking me, "Where are you from?" I have no idea what I would answer. (EX3)

Who are you, what, honestly, I say, I don't know! (EX4)

I like to travel a lot and I visited a lot of countries and when I travel there, if someone asks me where I'm from, I say I'm from Canada because I live in Canada. But after that, if we talk a bit more and they ask more, then I'll tell them that I was born in Bosnia and that I speak the Serbian language, so it depends on how the question was asked and how important it is to say where I come from. (EX6)

I am a bigger foreigner in Bosnia than here, though I don't know the language; in Serbia - what do I have there? (EX3) 
There is less and less doubt about the formation of hybrid identity and transculturalism, when one considers the self-reflectiveness of the respondents through which they become aware of the differences between them and their parents - the first generation of immigrants. This self-reflexivity also contributes to the perception of differences in the cultures of the country of origin and the host country.

For example, our parents and all the parents who came to Canada at the same time, they are still conservative, just as they are in Serbia and Bosnia. But we -I talk about myself, but I know that my friends do the same - we are much more liberal. (EX5)

Canada is somehow based on that multicultural side and these people are respected for what they are. I have no accent when I speak French, when I speak English, I have a slight accent because it is still my third language [...]. (EX2)

\section{The influence of primary socialisation on the (in)homogeneity of cultural identity}

When looking at the acculturation outcomes of the respondents from the second generation of $\mathrm{BiH}$ emigrants, one may conclude that primary socialisation has left a strong mark on the heterogeneity of their cultural identities. As a product of the absence of intergenerational conflict, as well as the existence of closeness to a network of peers originating from their own ethnic group, selective assimilation is noticeable.

To me, anyone in our region is already somehow closer to any Canadians here. It is very difficult to describe or explain at all. (EX2)

And as far as language is concerned, I'm aware that I'm making mistakes. I think it's quite up to the parents. I shouldn't, my parents didn't let me speak French or English, while some parents allowed it. (EX5)

When it comes to the preservation of the mother tongue and its use, most respondents agreed to use their mother tongue more frequently within the family. They emphasise this moment as the default routine in family relations. Maintaining the mother tongue in order to prevent barriers with family and friends within their ethnic group was the goal of primary socialisation. Language remains the most powerful symbolic tool for at least partially preserving one's cultural identity. The mother tongue is notably present on a daily basis among members of the second generation who have preserved and enriched social capital within their ethnic group. 
Well, I just use my mother tongue with them [my parents], I don't use my mother tongue every day. Less often than Finnish. With my parents, my brother and these three friends. (EX1)

In the house we certainly only speak Serbian, because I cannot even imagine my parents addressing me in French with those heavy accents. They only really speak in it at work when they have to. (EX2)

\section{Second-generation connections with the country of origin and the host country}

Although the respondents indicated that language as a symbolic tool plays a significant role in maintaining relationships with family and a certain group of friends, the answers regarding their immediate relationship with the place of origin suggest that they do not possess many other symbolic means. The folklorisation of the native culture and an ambivalent attitude towards society in Bosnia and Herzegovina seem to occasionally show undetermined position toward country of origin. The emphasis on functional life in the receiving country, in parallel with the personal experience of the political situation in the country of origin, places the second generation in a kind of interspace.

That's usually it, you visit where you were born, you hang out a little bit, sometimes you can see some old friends, you go to other big cities the rest of the time and that's it. Resting. You kind of feel after all these years as a tourist there. [...] Most international people who have some connections, who have not left very young..., they think about it [the situation in Bosnia]. They think a lot about it and it is very unfortunate to everyone that things are going on there, that progress is going very slowly, how good things have been, many things have been destroyed, how the regime is dysfunctional, the state as it is, corruption and all that. It is because of these facts that most young people will not return until something improves. (EX1)

We were always coming back... When we were little; Mom and Dad took us to Bosnia and went to Serbia every summer, usually every other summer, it depends. (EX6)

Our people are wonderful and all that, but somehow, that kind of fear or I don't know if it's fear, but respecting the law, even the unwritten rules, I think it's a little stronger here. I guess if you don't follow the rules here, you will be punished. (EX5) 
Almost none of the respondents expressed a complete sense of alienation from their country of origin. In addition to family and friendship relationships, holidays in the country of origin, the second generation of emigrants from Bosnia and Herzegovina maintains contacts with their birthplace through social networks and other means of communication. There is a desire to be informed about the progress and quality of life in the country of origin, which points to an emotional attitude towards the place of birth. However, no respondent from the second generation of emigrants expressed a desire to return.

I don't feel alienated. I go down to our house almost every year, whenever I can. (EX2)

This is how I know what's going on in BiH, it's more often they hear it through social networks or what my relatives tell me. (EX5)

Otherwise, when I interact with friends who live there, with family, these topics come up, but I have to admit, I am more involved in political life here, in cultural local decisions here, since I still live here. And it kind of touches me personally, as in Bosnia [...] you somehow care more about them being well because you have a sense of belonging. (EX2)

\section{CONCLUSION}

From the historical perspective of acculturation research, this process visibly depends on social transformations, among other things. Accordingly, acculturation processes at the group level and theories that help us understand these processes will depend on the type of society - whether it is open or closed. However, what needs to be addressed in exploring contemporary processes of acculturation is that cultural contact (and therefore acculturation) takes place at a subcultural level. Most theories (especially unidimensional and bidimensional) assume that the acculturation of immigrant groups takes place in a dominant culture that sets itself as coherent and ideal (one cannot overlook the Anglocentric background of these theories). This premise is unstable because no society is uniform but made up of subcultures, some of which are pathological. Also, no society has a hundred-percent consensus on diversity. Immigrant groups, on the other hand, are not authentic representatives of their culture, their communities are also heterogeneous, so the habits and traditions they bring to the host country may not necessarily reflect the overall culture they come from. In the words of Terry Eagleton (2016), diversity is sometimes beneficial, but sometimes not. Some forms of 
otherness will be respected, but some differences will not, mostly out of fear and there is nothing irrational about it. Cultural relativism is an implausible point of view, especially in transitional capitalism. "Far from producing citizens of the world, transnational capitalism tends to breed parochialism and insecurity among a large swathe of those subject to its sway; and it is towards racism and chauvinism, not into cosmopolitan cafés, that this insecurity is likely to impel them" (Eagleton, 2016: 158). With this in mind, we partly agree that cosmopolitism is a less likely result of societies with cultural pluralism. In every multicultural society, inside the consensus on differences, there is a place for the acceptance of racism and ethnocentrism, at least as deviations. This is why hybridisation is an inevitable process.

The second generation of young emigrants from Bosnia and Herzegovina is characterised by having strong contacts and building networks with their friends from the same ethnic community in the host country. The reason for the selective acculturation lies in the fact that the material and social capital offered by their ethnic communities enables better social mobility. However, these young people are not marked by ghettoisation within their own ethnic group, but because of their partial integration into a dominant society, they happen to be more likely to associate with emigrants from other ethnic communities, as they are brought closer by the experience of immigration. Relationships with the country of origin, which is most often perceived as unpromising and dysfunctional, enable them to adopt and respect the norms of behaviour in the host country faster. It is interesting to note that adaptation and integration are particularly noticeable in those young people living in countries whose immigration policy is open and in which cultural pluralism is expressed.

Interactive theories, such as the interactive acculturation model (IAM) by Bourhis et al. (1997), are a good avenue for studying second-generation acculturation, but they must include transculturality and hybrid identities as possible outcomes. These new identities are formed regardless of ethnic background or gender differences, but they are notably slower in circumstances where immigrants have developed homogenous communities. Life strategies may be variable, depending on multiple factors that orient subgroups of immigrants and, as such, have a great impact on the second generation (Bourhis et al., 1997). If we consider language as a symbolic tool that determines the direction of acculturation, then we could refer to the acculturation of second-generation emigrants from Bosnia and Herzegovina as selective, according to the model developed by Portes and Rumbaut. One 
of the most important findings of our research is that the second generation (2.0) of migrants does not have a clearly defined identity (which is symptomatic of 1.5 generations) and that their everyday life is marked by a conspicuous sense of unbelonging - neither there nor here. In this case, the fact that the second generation of $\mathrm{BiH}$ emigrants carries the characteristics of division reveals an important aspect that must be considered both in further research and in the development of integration policies.

\section{REFERENCES}

Al-Ali, N., Black, R. and Koser, K. (2001). The limits to "transnationalism": Bosnian and Eritrean refugees in Europe as emerging transnational communities, Ethnic and Racial Studies, 24 (4): 578-600, doi: https://doi.org/10.1080/01419870120049798

Alba, R. (2005). Bright vs. blurred boundaries: Second-generation assimilation and exclusion in France, Germany, and the United States, Ethnic and Racial Studies, 28 (1): 20-49, doi: https://doi.org/10.1080/0141987042000280003

Babić, B. (2013). The migration-development nexus in Bosnia and Herzegovina: Center for Local Development and Diaspora seen "from below", Southeast European and Black Sea Studies, 13 (2): 211-225, doi: https://doi.org/10.1080/14683857.2013.802173

Basch, L., Glick Schiller, N. and Szanton Blanc, C. (1994). Nations Unbound: Transnational Projects, Post-Colonial Predicaments and Deterritorialized Nation-States. London - New York: Routledge.

Berry, J. (1992). Acculturation and Adaptation in a New Society, International Migration, 30 (1): 69-85, doi: https://doi.org/10.1111/j.1468-2435.1992.tb00776.x

Bosnia and Herzegovina Ministry of Security (2019). Bosnia and Herzegovina Migration Profile for the Year 2018. Sarajevo.

Bourhis, R., Moise Lena, C., Perreault, S. and Senecal, S. (1997). Toward an Interactive Acculturation Model: A Social Psychological Approach, International Journal of Psychology, 32 (6): 369-386, doi: https://doi.org/10.1080/002075997400629

Clough, P., Goodley, D., Lawthom, R. and Moore, M. (2004). Researching Life Stories. London: Routledge, doi: https://doi.org/10.4324/9780203413371

Creswell, J. (2013). Qualitative Inquiry E Research Design: Choosing Among Five Approaches, 3rd Ed. Thousand Oaks: Sage Publications.

De Haas, H. (2005). International Migration, Remittances and Development: Myths and Facts, Third World Quarterly, 26 (8): 1269-1284, doi: https://doi.org/10.1080/ 01436590500336757

Eagleton, T. (2016). Culture. New Haven, CT: Yale University Press.

Gordon, M. (1964). Assimilation in American Life. The Role of Race, Religion, and National Origins. New York: Oxford University Press.

Kostić, R. (2013). Exploring Trends in Transnational Practices of Conflict-Generated Migrants: Bosnians in Sweden and their Activities towards Bosnia and Herzegovina, in: M. Emirhafizović, E. Ćosić, A. Osmić and V. Repovac-Pašić (eds). Migration from Bosnia and Herzegovina. Sarajevo: University of Sarajevo and Ministry for Human Rights and Refugees Department for Diaspora, 35-44. 
Morrow, R., Rodriguez, A. and King, N. (2015). Colaizzi's descriptive phenomenological method, The Psychologist, 28 (8): 643-644.

Neuman, W. L. (2007). Basics of Social Research: Qualitative and Quantitative Approaches, 2nd Ed. Boston: Pearson Education.

Park, R. E. (1928). Human Migration and the Marginal Man, American Journal of Sociology, 33 (6): 881-893, doi: https://doi.org/10.1086/214592

Portes, A. (1997). Immigration Theory for a New Century: Some Problems and Opportunities, International Migration Review, 31 (4): 799-825, doi: https://doi. org/10.1177/019791839703100402

Portes, A. and Rumbaut, R. (2001). Legacies. The Story of the Immigrant Second Generation. London: University of California Press.

Portes, A. and Zhou, M. (1993). The New Second Generation: Segmented Assimilation and Its Variants, Annals of the American Academy of Political and Social Science, 530 (1): 74-96, doi: https://doi.org/10.1177/0002716293530001006

Savić, D., Pepić, A. and Trninić, D. (2018). Life-Stories of Labour Migrants from Bosnia and Herzegovina: Balkanist Discourse(s), Liminality and Integration, Journal of Balkan and Near Eastern Studies, 22 (1): 121-137, doi: https://doi.org/10.1080/194489 53.2018.1506299

Teddlie, C. and Tashakkori, A. (2009). Foundations Of Mixed Methods Research. Los Angeles: SAGE.

Valenta, M. and Strabac, Z. (2013). Bosnians in Norway: Integration of Bosnian Migrants and their Descendants into Norweigan Society, in: M. Emirhafizović, E. Ćosić, A. Osmić, and V. Repovac-Pašić (eds). Migration from Bosnia and Herzegovina. Sarajevo: University of Sarajevo and Ministry for Human Rights and Refugees Department for Diaspora, 23-34.

Vertovec, S. (2001). Transnationalism and Identity, Journal of Ethnic and Migration Studies, 27 (4): 573-582, doi: https://doi.org/10.1080/13691830120090386

Zhou, M. (1997). Growing Up American: The Challenge Confronting Immigrant Children and Children of Immigrants, Annual Review of Sociology, 23 (1): 63-95, doi: https://doi.org/10.1146/annurev.soc.23.1.63

\section{Osjećaj (ne)pripadanja: iskustva akulturacije druge generacije emigranata iz Bosne i Hercegovine}

\section{Bojana Vukojević}

\section{SAŽETAK}

Suvremena istraživanja migracija pokazuju da se broj migranata rođenih u inozemstvu povećava, zbog čega ističu važnost istraživanja druge generacije migranata, kao posebne skupine koja može uputiti na specifičnosti migrantskog života i smjerove razvoja kulturnog identiteta. Pojam druga generacija odnosi se na osobe rođene u zemlji primitka, kojima je najmanje jedan roditelj imigrant, ili na osobe koje su emigrirale iz zemlje porijekla sa šest godina ili manje. S druge strane, generacija 1,5 (osobe rođene u stranoj zemlji iz koje su emigrirale u ranoj adolescenciji - između šest i dva- 
naest godina) ne iskazuje jedinstven kulturni identitet, već osjeća podijeljenost između pripadanja zemlji porijekla i zemlji primitka. Prema studijama migracija, druga generacija pokazuje bolju razinu akulturacije, koja se odnosi na lakše učenje jezika i usvajanje obrazovnih i radnih navika. Rad ispituje različite teorijske modele (jednodimenzionalni, dvodimenzionalni i interaktivni) kako bi pronašao okvir za iskustva akulturacije druge generacije emigranata iz Bosne i Hercegovine. Primjenjujući diskurzivnu analizu životnih priča šest ispitanika - druge generacije emigranata iz $\mathrm{BiH}$, kreiran je interpretativni okvir koji se sastoji od tri teme: samoodređenje i konstrukcija identiteta; utjecaj primarne socijalizacije na (ne)homogenost kulturnog identiteta te povezanost druge generacije sa zemljom porijekla i zemljom primitka. Najvažniji je zaključak da druga generacija nema jasno formiran identitet (što je simptomatično za generaciju 1,5) i da je njihov svakodnevni život obilježen intenzivnim osjećanjem nepripadanja - ni tamo, ni ovdje.

KLJUČNE RIJEČI: druga generacija, migracija, akulturacija, identitet, pripadanje 